JAKUB PIGOŃ

Uniwersytet Wrocławski

ORCID 0000-0001-9272-7490

e-mail: jakub.pigon@uwr.edu.pl

\title{
PATRZENIE JAKO ŹRÓDŁO CIERPIEŃ (Z RZYMSKICH DZIEJÓW PEWNEGO MOTYWU LITERACKIEGO)
}

\begin{abstract}
Pigoń Jakub, Patrzenie jako źródło cierpień (z rzymskich dziejów pewnego motywu literackiego) (Sight and Suffering: From the Roman History of a Literary Motif).

The paper examines a number of Roman literary texts (by Ennius, Cicero, Vergil, Ovid, Seneca the Younger, Lucan, Tacitus, Jerome, etc.) in which viewing is connected with mental or emotional suffering. Usually, the emphasis is laid on a character's viewing of some dramatic events - a close relative's death, for example - and on his or her emotional response to what is being seen. In some works, especially in consolatory contexts, someone's premature death is presented as advantageous because the dead person is now spared the necessity of viewing misfortunes which the living have to witness. Also, people may be compelled (e.g. by an emperor) to watch evil things; in such a situation they are usually viewers and objects of viewing at the same time, since their gestures and facial expression are carefully observed.
\end{abstract}

Keywords: viewing as a literary theme; Roman literature; Cicero; Vergil; Seneca the Younger; Tacitus; consolation

Uśmiechał się właśnie świt pogodnego dnia i słońce oświetliło szczyty, gdy zza góry, która rozciąga się nad jednym z ujść Nilu zwanym ujściem Heraklesa, wyłonili się mężczyźni uzbro-

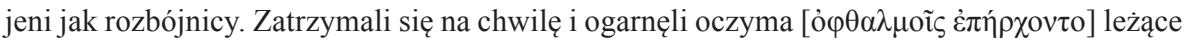

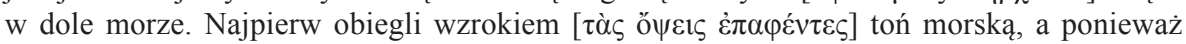

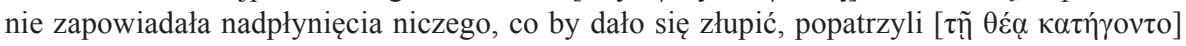
w stronę pobliskiego brzegu. Oto, co na nim ujrzeli.

Tak rozpoczyna się opis tajemniczego pobojowiska na brzegu morskim, w pobliżu opuszczonego przez załogę okrętu; jest to pierwsza scena Opowieści etiopskiej Heliodora, pochodzącego z III lub IV w. n.e. greckiego utworu, którego polski przekład zawdzięczamy Profesorowi Sylwestrowi Dworackie$\mathrm{mu}^{1}$. Pobojowisko to rezultat wydarzeń, których przebiegu i znaczenia narrator

${ }^{1}$ Heliodor, Opowieść etiopska o Theagenesie i Chariklei.... Przekład: Sylwester Dworacki. Kolejny cytat też w tym tłumaczeniu. 
chwilowo przed odbiorcą nie wyjawia; zostaną one przedstawione dopiero w ks. V. Teraz natomiast czytelnik ogląda ów „krajobraz po bitwie” oczami rozbójników, którzy u Heliodora są „,wewnętrznymi widzami”; widzi i wie tyle, co widzą i czego domyślają się tamci. Na uwagę zasługuje słownictwo odnoszące się do

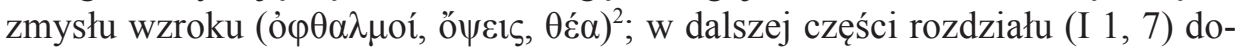
chodzi do tego frapująca metaforyka widowiska teatralnego ${ }^{3}$ :

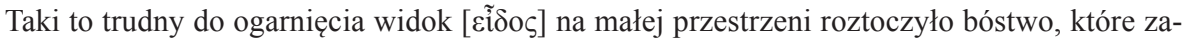
mąciło wino krwią, biesiadę przemieniło w bitwę, pijatykę w bijatykę, płynne ofiary w rzeź a całe to widowisko [ $\theta \dot{\varepsilon} \alpha \tau \rho o v]$ roztoczyło przed egipskimi rozbójnikami. Bo rzeczywiście

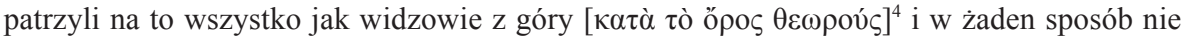

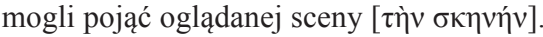

To zrównanie widzów wewnątrztekstowych i zewnętrznych (czyli odbiorców utworu) jest zabiegiem literackim, przy którym warto na chwilę się zatrzymać. W badaniach nad tekstami narracyjnymi coraz więcej uwagi poświęca się temu, co zwykło się określać jako „punkt widzenia w narracji”, a co w ostatnich dziesięcioleciach - pod wpływem prac Gérarda Genette'a, Mieke Bal czy, w odniesieniu do literatury antycznej, Irene de Jong ${ }^{5}$ - opisywane jest za pomocą terminu „fokalizacja”. W pierwszej scenie powieści Heliodora nośnikami fokalizacji („fokalizatorami”) są egipscy rozbójnicy; narrator obserwuje scenę pobojowiska właśnie z ich perspektywy - i taką perspektywę przyjąć musi, chcąc nie chcąc, również odbiorca.

Zilustrujmy to jednym przykładem, zaczerpniętym już - zgodnie z zakresem tematycznym tego artykułu - z literatury rzymskiej. W IV ks. Eneidy Wergiliusz porównuje przygotowujących się do odpłynięcia z Kartaginy Trojan do mrówek, które pracowicie znoszą z pola ziarna zboża (IV 402-407). Wers bezpośrednio poprzedzający to porównanie brzmi: „migrantis cernas totaque ex urbe ruentis” (401). Pojawia się w nim co prawda czasownik odnoszący się do zmysłu wzroku (cernas), ale nic nie wskazuje na to, by dotyczył on jakiejś postaci wewnątrz

${ }^{2} \mathrm{~W}$ związku z aspektem wizualnym sceny początkowej Opowieści etiopskiej zob. Bühler 1976; Telò 2011.

${ }^{3}$ Metaforyka teatralna (stosowana przez Heliodora nie tylko w tym miejscu) służy uwydatnieniu związków między Opowieścią etiopska a dramatem i teatrem. Na ten temat zob. Dworacki 1996.

${ }^{4}$ Rozbójnicy znajdują się na wzgórzu (cf. I 1, 1) i stamtąd obserwują pobojowisko nad brzegiem morza. Spoglądają więc z góry ku dołowi - tak jak widzowie w greckim teatrze, siedzący na amfiteatralnej widowni.

${ }^{5}$ Zob. Genette 1972: 206-223; Bal 2012: 146-166 (pierwsze wydanie tej książki ukazało się w 1985 r.); de Jong 1987. Dobrym, bogato ilustrowanym przykładami wprowadzeniem do narratologicznej lektury tekstów grecko-łacińskich jest książka de Jong (2014); o fokalizacji na s. 47-72. „Punkt widzenia w narracji” (pojęcie wprowadzone do dyskursu literaturoznawczego przez powieściopisarza Henry'ego Jamesa): zob. np. Scholes, Kellogg 1966: 240-282 (liczne odniesienia do literatury antycznej). 
tekstu; ma w istocie znaczenie bezosobowe („można by zobaczyć”). Owo cernas jest jednak zwodnicze, ponieważ Wergiliusz w końcu wyjawia, z jakiej perspektywy oglądamy „mrowiących się” Trojan. Porównanie się kończy, zaraz po nim następuje apostrofa (408-411):

Quis tibi tum, Dido, cernenti talia sensus, quosve dabas gemitus, cum litora fervere late prospiceres arce ex summa, totumque videres misceri ante oculos tantis clamoribus aequor.

[Wszystkie pogrubienia w cytatach łacińskich zostały dodane przez autora artykułu - J. P.]

Wprowadzone tutaj wyróżnienia graficzne pokazują, jak mocno eksponuje Wergiliusz zmysł wzroku'. Patrzy oczywiście Dydona, która znajduje się w górnej części swojego pałacu (arce ex summa); spogląda z wysoka w dół i widziani stamtąd Trojanie istotnie mogą przypominać mrówki. Tego porównania nie możemy do końca zrozumieć, nie uwzględniając postaci wewnątrz tekstu, której perspektywę przyjmuje narrator ${ }^{7}$.

Warto rozpatrywać porównanie do mrówek z ks. IV w zestawieniu z porównaniem do pszczół z ks. I (I 430-436; cf. Georg. IV 162-169) ${ }^{8}$. Eneasz wspiął się na wzgórze w pobliżu Kartaginy i stamtąd z podziwem obserwuje (dwukrotne miratur na początku wersów 421 i 422), jak jej mieszkańcy trudzą się, wznosząc nowe miasto - właśnie niczym rój pszczół, które pracowicie spełniają rozmaite zadania. Zarówno Eneasz, jak i Dydona są obserwatorami emocjonalnie zaangażowanymi w to, co rozgrywa się przed ich oczami - z tą jednak różnicą, że emocje Eneasza są pozytywne - widok budowanego miasta skłania go do myśli o mieście, które on sam ma założyć ${ }^{9}$ - natomiast emocje Dydony negatywne; to,

${ }^{6}$ Przy czym pojawiające się jako pierwsze cernenti odsyła do cernas z wersu 401. Można zaryzykować tezę, że apostrofa do Dydony nadaje ex post inną wymowę tamtemu czasownikowi użycie, które traktowaliśmy dotąd jako bezosobowe, może w istocie zapowiadać pojawienie się Dydony jako osoby patrzącej.

${ }^{7}$ Zob. Briggs 1980: 55: „,...the most unusual effect of the simile comes after its climactic buildup, when the poet suddenly turns and addresses Dido herself [...]. We realize then that we have been prepared by Virgil not only to see the Trojans as ants through his eyes, but in fact through Dido's eyes..." W podobny sposób - choć nie dotyczy to już porównania, tylko rozbudowanej ekfrazy - dowiadujemy się dopiero ex post, że narzutę przykrywającą łoże małżeńskie Peleusa i Tetydy w utworze 64 Katullusa oglądamy w istocie oczami tesalskiej młodzieży, która przybyła do pałacu jako goście weselni (Catull. 64, 267-268; cf. 47-51).

${ }^{8} \mathrm{~W}$ obu porównaniach wymienione zostają różne grupy owadów, każda zajmująca się innym zadaniem (I 432-434 : ,aut [...] aut [...] aut” IV 405-406: „pars [...] pars”); oba kończą się podobnie (I 436: „fervet opus” IV 407: „opere omnis semita fervet”).

${ }^{9}$ I 437: „O fortunati, quorum iam moenia surgunt!”. 
co widzi, jest dla niej udręką, pobudza do żałosnego jęku ${ }^{10}$. Inaczej u Heliodora - rozbójnicy przyglądają się z zaciekawieniem i próbują dociec, co wydarzyło się na brzegu morskim, ale sam widok nie wywołuje w nich emocji; jeśli coś je wzbudza, to perspektywa zdobycia łupów.

W dalszej części tego artykułu chciałbym się zająć właśnie motywem obserwatora zaangażowanego, dla którego - tak jak dla Dydony - przyglądanie się czemuś jest doświadczeniem traumatycznym. Wariantem tego motywu jest pojawiająca się w utworach o charakterze konsolacyjnym refleksja, że lepiej się stanie, jeśli jakiejś osobie zostanie oszczędzona konieczność oglądania nieszczęść - oszczędzona w ten sposób, że los w stosownym czasie zabierze ją $\mathrm{z}$ tego świata. $\mathrm{Z}$ jeszcze innym wariantem mamy do czynienia $\mathrm{w}$ tych tekstach, w których mowa jest o przymusie patrzenia; o tym, że oglądanie czegoś (a równocześnie bycie oglądanym) może być dodatkową, szczególnie okrutną karą.

Pozostańmy chwilowo w obrębie poematu Wergiliusza. Słynna wypowiedź Eneasza podczas zesłanej przez Junonę burzy morskiej - jego pierwsze słowa w Eneidzie - zaczyna się następująco (I 94-96):

O terque quaterque beati,

quis ante ora patrum Troiae sub moenibus altis

contigit oppetere!

Cały monolog Trojanina (94-101) to oczywiście nawiązanie do analogicznego monologu Odyseusza (Hom. Od. V 306-312). Wergiliusz modyfikuje passus z Odysei, dostosowując wypowiedź swojego bohatera do nowej sytuacji ${ }^{11}$. U Homera też pojawia się eksklamacja „trzykroć, czterykroć szczęśliwi”, ale nie ma wzmianki o śmierci na oczach ojców - bo ojcowie greckich wojowników nie byli świadkami walk pod murami Troi. Sformułowanie „Troiae sub moenibus altis" ewokuje znany z Iliady motyw oglądania walk z murów miasta (teichoskopia), tu przede wszystkim w związku ze śmiercią Hektora, której obserwatorami byli stojący na murach Priam i Hekuba ${ }^{12}$. Nieprzypadkowo w dalszej części monologu Eneasz wymienia właśnie Hektora, a ponadto Sarpedona, jako tych, którzy polegli pod Troją i których losu nie dane mu było wówczas podzielić (97-100) - ponieważ obaj ci bohaterowie zginęli na oczach swych ojców ${ }^{13}$.

\footnotetext{
${ }^{10}$ Zwróćmy uwagę nas kontrast między odnoszącym się do Dydony gemitus (IV 409) a odnoszącym się do Trojan clamoribus (411).

${ }^{11}$ Zdaniem niektórych badaczy Eneasz, w przeciwieństwie do Odyseusza, w tym monologu jawi się jako bohater „nieheroiczny”. Z poglądami tymi polemizuje słusznie Stahl (1981).

${ }^{12}$ Zob. Hom. Il. XXII 405-409. Homerowy narrator przenosi się z równiny trojańskiej, gdzie Achilles wlecze za rydwanem zwłoki Hektora, na mury miasta, opisując reakcję rodziców na śmierć syna i poniewieranie jego ciała. Wcześniej rodzice próbowali bezskutecznie nakłonić Hektora, by nie podejmował walki z Achillesem (33-91).

${ }^{13}$ Ojcem Sarpedona był Zeus, który uległ argumentom Hery i przystał na nakazaną wyrokiem losu śmierć syna z rąk Patroklosa (Hom. Il. XVI 431-461). Na związek między wzmianką
} 
Wergiliusz, rzecz jasna, nie wspomina o śmierci ante ora patrum po to tylko, by wzorowanej na Odysei wypowiedzi Eneasza nadać „koloryt trojański”. Badacze słusznie zwracają uwagę na to, jak ważną rolę w poemacie odgrywa motyw przedwczesnej śmierci synów, w obliczu której stawać muszą ich rodzice (czasem dosłownie „w obliczu”, gdyż widzą tę śmierć, czasem zaś wtedy, gdy się o niej dowiadują) $)^{14}$. Tytułem przykładu możemy wymienić Laokoona i jego synów (II 212-217), Politesa i Priama (II 526-543), Ikara i Dedala (VI 30-33, w ekfrazie), Euryala i jego matkę (IX 473-502), Laususa i Mezencjusza (X 833856) czy Pallasa i Ewandra (XI 139-181) ${ }^{15}$. Przywołanie przez Eneasza tych, którzy zginęli w Troi na oczach swych ojców jest zatem pierwszym w utworze odniesieniem do tego motywu. Zdaniem części badaczy Eneasz dlatego wspomina tych wojowników, ponieważ taką właśnie śmierć - ante ora patrum - postrzegano jako szczególnie pożądaną, wpisującą się w kanon epickiego bohatera; ojcowie jako świadkowie śmierci stawali się gwarantami sławy, która będzie udziałem poległych ${ }^{16}$. Ten pogląd jednak nie wytrzymuje konfrontacji z takimi epizodami jak ten opisujący śmierć Politesa z rąk Pyrrusa, syna Achillesa ${ }^{17}$. Śmiertelnie rannemu Pyrrusowi udaje się jeszcze podbiec do ołtarza, przy którym schronili się jego rodzice (II 531-532):

Ut tandem ante oculos evasit et ora parentum, concidit ac multo vitam cum sanguine fudit.

Priam (wcześniej Hekuba odwiodła go od udziału w walce) podejmuje beznadziejną próbę pomszczenia śmierci syna. Znamienne są słowa, które kieruje przy tym do Pyrrusa (535-539):

„At tibi pro scelere”, exclamat, ,pro talibus ausis

di, si qua est caelo pietas quae talia curet,

persolvant grates dignas et praemia reddant

o Hektorze i Sarpedonie w monologu Eneasza a motywem śmierci ante ora patrum zwraca uwagę O’Sullivan (2009: 456).

${ }^{14}$ Zob. np. Lee 1979. Motyw śmierci ante ora parentum w Eneidzie analizuje w ważnym artykule O'Sullivan (2009), interpretując go m.in. w kluczu metapoetyckim.

${ }^{15} \mathrm{~W}$ tym kontekście należałoby też wspomnieć o siostrzeńcu Augusta, Marcellusie, którego mającą w odległej przyszłości (w 23 r. p.n.e.) nastąpić śmierć opłakuje w Podziemiu Anchizes (poniekąd in vice patris), zob. VI 867-886. W zamykającej poemat scenie śmierci Turnusa ważną rolę odgrywa jego ojciec, którego wódz Rutulów wspomina w swojej ostatniej mowie (XII 931-936).

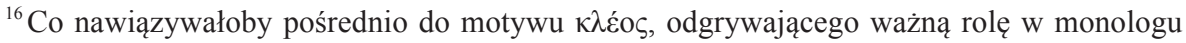
Odyseusza (V 311-312), niepojawiającego się jednak explicite w wypowiedzi Eneasza. W takim duchu np. Stahl 1981: 161: „Aeneas' desire goes for the proudest, most glorious death, since «before the eyes of the fathers» he could achieve paternal recognition of his heroism - as opposed to the present threat of drowning in inglorious anonymity".

${ }^{17}$ Zob. O’Sullivan 2009: 458-462. 
debita, qui nati coram me cernere letum

fecisti et patrios foedasti funere vultus" ${ }^{\text {. }}$.

Śmierć na oczach ojców jest więc czymś szczególnie godnym pożałowania właśnie z perspektywy tych, którzy śmierć swoich najbliższych muszą oglądać. Początek monologu Eneasza w ks. I ma zatem wymowę paradoksalną - nawet ci, którzy w taki sposób zginęli, są mimo wszystko trzykroć, czterykroć bardziej szczęśliwi od trojańskiego wodza. Jego bowiem - jak się wydaje - pochłoną morskie odmęty. Wergiliusz, nawiązując do Homera, czyni swoją wypowiedź bardziej dobitną; naśladownictwo (imitatio) ustępuje miejsca rywalizacji (aemulatio).

Priam był świadkiem śmierci Politesa, a wkrótce potem sam zginął. Warto przy tym pamiętać, że obydwa zgony - i wszystko to, co rozgrywało się w pałacu królewskim - oglądał w poemacie Wergiliusza ktoś inny - Eneasz ${ }^{19}$, który siedem lat później na dworze królowej Dydony snuje swoją opowieść o upadku Troi. Eneasz jako narrator stosunkowo rzadko posługuje się określeniami wskazującymi na to, że sam coś naocznie widział (tak II 212, 347, 561, 624); na tle tych sporadycznych wzmianek szczególnie wyraźnie rysuje się następujący passus, podsumowujący to, co działo się w pałacu, gdy wtargnęli tam Grecy (II 499-502; rozbudowany opis śmierci Priama Eneasz dodaje później):

Vidi ipse furentem

caede Neoptolemum geminosque in limine Atridas,

vidi Hecubam centumque nurus Priamumque per aras

sanguine foedantem quos ipse sacraverat ignis.

Anafora podkreśla emocjonalne zaangażowanie Eneasza; nie jest on bynajmniej beznamiętnym obserwatorem ${ }^{20}$. Pierwsze vidi odnosi się do agresorów, przy czym szczególny nacisk położony jest na wymienionego najpierw Neoptolemusa (Pyrrusa), który wkrótce zostanie ukazany jako zabójca Priama. Drugie vidi odnosi się do ofiar; Wergiliusz wprowadza tu tricolon crescens i uwydatnia jego ostatni element. Między obiema częściami wypowiedzi nie ma wyraźnego paralelizmu, ale „furentem / caede Neoptolemum” możemy zestawiać

\footnotetext{
${ }^{18}$ Pomijam dalszą część wypowiedzi Priama (540-543), gdzie Neoptolemus zostaje przeciwstawiony swojemu ojcu, Achillesowi.

${ }^{19}$ Eneasz znalazł się na dachu pałacu Priama; stamtąd stara się wraz z innymi Trojanami kontynuować działania obronne (II 453-468). Zarazem miejsce to jest dobrym punktem obserwacyjnym. Na wydarzenia rozgrywające się w pałacu Eneasz patrzy z góry, trochę jak rozbójnicy z pierwszej sceny Opowieści etiopskiej Heliodora. Jest więc poniekąd widzem w teatrze - choć Wergiliusz nie posługuje się tu metaforyką teatralną. Nawiązania do tragedii Enniusza, o których będzie mowa, dobrze wpisują się w rolę Eneasza jako widza.

${ }^{20}$ Zwraca na to uwagę Serwiusz auctus w komentarzu ad loc.: „Sane «vidi ipse» hac particula addita miseriorem se ostendit, cuius ante oculos casus patriae suorumque fortuna constituerat". Cf. Verg. Aen. II 5.
} 
$\mathrm{z}$ „Priamumque $[\ldots]$ / sanguine foedantem”; inicjalna pozycja w heksametrze podkreśla odpowiadające sobie rzeczowniki caede i sanguine (pamiętamy, że caedes może znaczyć też ' krew'). W istocie - ponieważ Priam ginie z ręki Neoptolemusa - mowa jest o tym samym wydarzeniu, ale ukazanym $\mathrm{z}$ dwóch perspektyw; najpierw wzrok Eneasza spoczywa na zabójcy, potem na zabitym.

To anaforyczne vidi jest zarazem wskazówką, że mamy tu do czynienia z literackim zapożyczeniem. W ks. II Eneidy Wergiliusz chętnie sięga po tragedie Enniusza odnoszące się do cyklu trojańskiego ${ }^{21}$. Wielkiemu admiratorowi Enniusza, Cyceronowi, zawdzięczamy następujący fragment z Andromachy (Enn. Trag. 87-94 Jocelyn = Cic. Tusc. III 44-45):

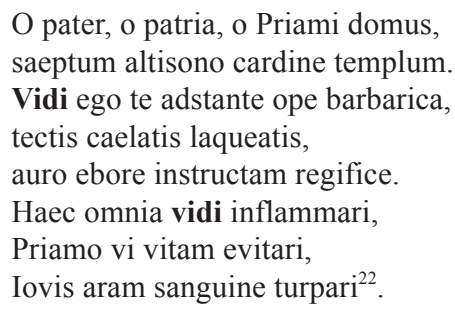

To, co u Enniusza widziała Andromacha, u Wergiliusza widzi Eneasz. O ile jednak w Eneidzie anafora vidi służy uwydatnieniu kontrastu między agresorami a ich ofiarami, w tragedii Enniusza wskazuje raczej na kontrast między wspaniałą, bogatą w złoto i kość słoniową przeszłością królewskiego domu Priama a jego nędznym końcem ${ }^{23}$. W przytoczonym fragmencie greccy zdobywcy w ogóle nie są wymienieni; jedynie trzy bierne infinitiwy (inflammari, evitari, turpari) pośrednio wskazują na ich obecność. Obaj autorzy kończą mocnym obrazem ołtarza zbrukanego krwią ${ }^{24}$. Również w tym wypadku (tak jak w monologu Eneasza

${ }^{21}$ Zob. np. Stabryła 1970: 75, 81-83; Wigodsky 1972: 76-78; Elliott 2008.

${ }^{22}$ Do tego fragmentu Wergiliusz odwołuje się także w II 241-242 (,o patria, o divum domus Ilium et incluta bello / moenia Dardanidum!”) oraz w II 504 (,,barbarico postes auro spoliisque superbi").

${ }^{23} \mathrm{~W}$ Eneidzie ten kontrast zostaje ukazany później, najpierw w wersach 503-505 (a zatem bezpośrednio po analizowanym tu passusie; tam też nawiązanie do Enniusza, zob. przyp. 22), a w sposób szczególnie dobitny w „epitafium” Priama (554-558). Z anaforą عĩoov (= vidi) w analogicznym kontekście spotykamy się w wypowiedzi Hekuby w Trojankach Eurypidesa (Eur. Troad. 479-484); nie ma tam kontrastu; pierwsze ,widziałam” odnosi się do śmierci dzieci, drugie

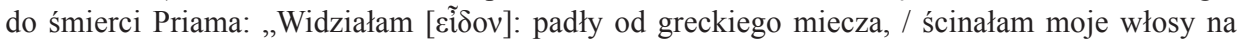
ich grobach. / Tego, co spłodził je - Priama, płakałam, / nie wieść z ust obcych słysząc, lecz na

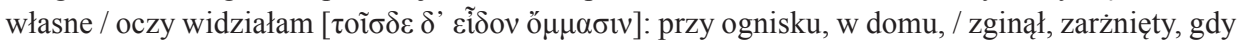
zdobyto miasto" (przeł. J. Łanowski).

${ }^{24}$ Jocelyn (1969: 251) zwraca uwagę na to, że w greckich przekazach dotyczących śmierci Priama motyw ten nie występuje, jest to więc zapewne dodatek Enniusza. Priam, który jest kapłanem (jako głowa rodu, a przede wszystkim jako król), sam staje się żertwą ofiarną. Z podobnym odwróceniem ról spotykamy się w ks. II Eneidy w epizodzie Laokoona (199-227). Ciekawej 
z ks. I) Wergiliusz podejmuje poetycką aemulatio ze swoim wzorcem: po pierwsze wzmacnia patos sceny, dodając „,quos ipse sacraverat” ${ }^{25}$, po drugie zaś ołtarz zastępuje ofiarnym ogniem, który się na nim pali ${ }^{26}$. U Enniusza ogień jest narzędziem zniszczenia, którym posługują się greccy zdobywcy (inflammari); Wergiliusz dokonuje poetyckiej transformacji tego ognia, czyniąc zeń swoisty symbol daremnej pietas starego króla ${ }^{27}$. Ze słów ,sanguine foedantem [...] ignes" ${ }^{\text {"28 }}$ nie musi wynikać, że krew Priama ugasiła płomień na ołtarzu; u późniejszych autorów - być może pod wpływem Wergiliusza - spotykamy się z tym motywem, przede wszystkim w odniesieniu do świętego ognia Westy ${ }^{29}$.

Kilkadziesiąt lat po Wergiliuszu Seneka w Agamemnonie kilkakrotnie wspomni śmierć Priama, która $\mathrm{w}$ tej tragedii zostaje symbolicznie skojarzona ze śmiercią tytułowego bohatera ${ }^{30}$. Jedno z przywołań pojawia się w pieśni chóru branek trojańskich (Sen. $A g$. 649-658):

$$
\begin{aligned}
& \text { Quid nunc primum, dolor infelix, } \\
& \text { quidve extremum deflere paras? } \\
& \text { Moenia divum fabricata manu, } \\
& \quad \text { diruta nostra? } \\
& \text { An templa deos super usta suos? } \\
& \text { Non vacat istis lacrimare malis: } \\
& \text { te, magne parens, flent Iliades. } \\
& \text { Vidi, vidi senis in iugulo } \\
& \text { telum Pyrrhi vix exiguo } \\
& \text { sanguine tingui. }
\end{aligned}
$$

W tej partii chóru (589-658) trzykrotnie jeszcze pojawia się czasownik videre $\mathrm{w}$ odniesieniu do nieszczęść, których świadkami były Trojanki, gdy ich miasto zdobywali Grecy, lub do zdarzeń poprzedzających te nieszczęścia:

paraleli dostarcza Łk 13, 1: ,...przyszli niektórzy i donieśli Mu o Galilejczykach, których krew Piłat zmieszał z krwią ich ofiar" (przekład Biblii Tysiąclecia). Cf. także Val. Max. IX 2, 2 o Juniuszu Brutusie Damazyppie: „cuius iussu principum civitatis capita hostiarum capitibus permixta sunt”.

${ }^{25}$ Serwiusz komentuje ad loc.: ,,per quod ostenditur latenter nihil prodesse religionem”. Cf. Verg. Aen. II 429-430.

${ }^{26}$ Zob. Rivoltella 2005: 3-6.

${ }^{27}$ Trzy wersy później mamy jednak ogień zniszczenia: „tenent Danai qua deficit ignis” (II 505). Na temat motywu ognia w Aen. II zob. Knox 1950.

${ }^{28}$ Cf. Verg. Aen. X 519-520: ,inferias quos immolet umbris / captivoque rogi perfundat sanguine flammas"; XI 82: „,caeso sparsurus sanguine flammas”.

${ }^{29} \mathrm{~Np}$. Ov. Met. XV 777-778: „neve / caede sacerdotis flammas extinguite Vestae” (o zabójstwie Juliusza Cezara); Lucan. II 126-129 (zob. Brena 1993); Sil. It. IV 411. Ale o ogniu ugaszonym krwią czytamy już u Cycerona, Dom. 144: „teque, Vesta mater, cuius sanctissimas sacerdotes ab hominum amentium furore ac scelere defendi cuiusque ignem illum sempiternum non sum passus aut sanguine civium restingui aut cum totius urbis incendio commisceri". Ciekawe przekształcenie tego motywu znajdujemy u Hieronima, Epist. 60, 3, 4 (krew Chrystusa gasi płonący miecz strzegący wejścia do raju).

${ }^{30}$ Zob. Lohikoski 1966. 
„vidimus patriam ruentem / nocte funesta” (611-612); „vidimus simulata dona / molis immensae" (625-626, o koniu trojańskim); ,et, quod numquam post Hectoreos / vidimus ignes, laeta est Hecabe" (647-648, w opisie radosnej reakcji Trojan, przekonanych, że Grecy już odpłynęli). „Vidi, vidi” (656) zamyka ten retrospektywny przegląd, a śmierć Priama stanowi - podobnie jak w ks. II Eneidy - punkt szczytowy i kwintesencję tragedii miasta. Ponieważ słowa te wypowiada chór, przejście z liczby mnogiej do pojedynczej może wydawać się niezrozumiałe - ale tylko wtedy, gdy zignorujemy fakt, że Seneka odwołuje się tutaj do Wergiliusza i do Enniusza (w tym drugim wypadku pozostając w obrębie tego samego gatunku literackiego). Andromacha Enniusza, a potem Eneasz Wergiliusza, stają się zatem podmiotem zbiorowym - chórem kobiet trojańskich. Użyta przez Senekę geminatio niewątpliwie służy wzmocnieniu patosu (cf. Quint. Inst. IX 3, 28), ale jest też wyraźnym sygnałem, że mamy do czynienia z literacką aluzją ${ }^{31}$. Inaczej niż jego poprzednicy, Seneka ogranicza się do jednej wypowiedzi składniowo podporządkowanej vidi; nie wprowadza kontrastu między świetnością a upadkiem (jak Enniusz) czy między agresorami a ich ofiarami (jak Wergiliusz) ${ }^{32}$.

Ten sam Cyceron, któremu zawdzięczamy fragment z Andromachy Enniusza, w ks. I Rozmów tuskulańskich przywołuje Priama na poparcie tezy, że śmierć może nas uwalniać od nieszczęść, nie zaś odrywać od pomyślności; że długie życie niekoniecznie jest tym, czego powinniśmy sobie życzyć. Gdyby Priam umarł wcześniej (,adstante ope barbarica, tectis caelatis laqueatis" - tu również Arpinata cytuje Andromachę), odchodziłby z tego świata jako człowiek szczęśliwy. Podobnie z Pompejuszem - gdyby ciężka choroba (zapadł na nią w 50 r. p.n.e.) zakończyła się śmiercią, zostałyby mu oszczędzone wszystkie udręki, które stały się jego udziałem po wybuchu wojny domowej (Cic. Tusc. I 85-86) ${ }^{33}$. Te dwa exempla pojawiają się też w dziesiątej satyrze Juwenalisa; poeta polemizuje z poglądem, że jednym z dóbr, o które powinniśmy prosić bogów, jest długie życie ${ }^{34}$. O Priamie pisze Juwenalis między innymi tak (Iuven. 10, 265-270):

${ }^{31}$ „Allusion marker” w terminologii Ben-Porat (1988: 319).

${ }^{32} \mathrm{Cf}$. Sen. Herc. fur. 254-258 (Amfitrion o zagładzie królewskiego domu w Tebach - Kreona i jego synów). Powtórzone vidi jest tutaj użyte anaforycznie z dwoma różnymi dopełnieniami, nie ma jednak kontrastu (raczej, na poziomie symbolicznym, gradacja).

${ }^{33} \mathrm{O}$ Pompejuszu m.in.: „Qui, si mortem tum obisset, in amplissimis fortunis occidisset, is propagatione vitae quot, quantas, quam incredibilis hausit calamitates!". To zapewne ten passus z Rozmów tuskulańskich, w którym przykład Pompejusza następuje bezpośrednio po przywołaniu króla Troi, dał asumpt późniejszym autorom - przede wszystkim Wergiliuszowi i Lukanowi - do aluzyjnego kojarzenia śmierci Priama ze śmiercią Pompejusza (lub vice versa); zob. Bowie 1990; Berno 2004; Petrone 2008.

${ }^{34}$ Cały ten passus obejmuje wersy $188-288$. By zilustrować swoją tezę, Juwenalis posługuje się m.in. przykładem Priama (258-272) i Pompejusza (283-288); między Priamem a Pompejuszem wspomniany jest Mariusz. 


\begin{abstract}
Longa dies igitur quid contulit? Omnia vidit eversa et flammis Asiam ferroque cadentem. Tunc miles tremulus posita tulit arma tiara et ruit ante aram summi Iovis ut vetulus bos, qui domini cultris tenue et miserabile collum praebet ab ingrato iam fastiditus aratro.
\end{abstract}

Juwenalis idzie tutaj najpewniej za Cyceronem, choć korzysta też z Wergiliusza; nie jest jasne, czy do Enniusza odwołuje się tylko za pośrednictwem Arpinaty czy z pierwszej ręki ${ }^{35}$. W każdym razie owo vidi, które - jak pamiętamy - odnosiło się najpierw do Andromachy, potem do Eneasza, wreszcie do branek trojańskich, tutaj (już w trzeciej osobie) odnosi się do samego Priama ${ }^{36}$.

Przywołajmy jeszcze Owidiusza, który w charakterystyczny dla siebie sposób ucieka się do paradoksu: w gruncie rzeczy nawet Priama, ginącego w zdobywanej przez Greków Troi, można uznać za człowieka szczęśliwego. Wszystko zależy od perspektywy. Tutaj, w ks. XIII Metamorfoz, przyjmujemy perspektywę Hekuby, której córka Poliksena została właśnie złożona w ofierze cieniom Achillesa (Ov. Met. XV 516-522):

Quo ferrea resto?

Quidve moror? Quo me servas, annosa senectus?

Quo, di crudeles, nisi uti nova funera cernam, vivacem differtis anum? Quis posse putaret felicem Priamum post diruta Pergama dici? Felix morte sua es $^{37}$; nec te, mea nata, peremptam aspicit et vitam pariter regnumque reliquit.

Tu również nieszczęście zostaje skojarzone z patrzeniem, choć inaczej niż w poprzednich przykładach nie pojawia się czasownik videre. Priam już nie musi oglądać tragicznych zdarzeń, które nie ustały wraz z upadkiem Troi. Do tej wypowiedzi Hekuby nawiąże potem Seneka w Trojankach: chór kobiet trojańskich

${ }^{35}$ Cyceron: Courtney 1980: 421 (np. Cic. Tusc. I 85: „hic si vivis filiis incolumi regno occidisset” Iuven. 10, 258: ,incolumi Troia Priamus venisset ad umbras”); Wergiliusz: Murgatroyd 2016. Zdaniem Murgatroyda porównanie do wołu nawiązuje do epizodu z Laokoonem (II 223-224: porównanie do byka); może to być jednak odniesienie do tekstów, w których śmierć Agamemnona przyrównywano do zaszlachtowania wołu lub byka (Hom. Od. IV 535 = XI 411; Aesch. Ag. 1126; Sen. Ag. 776-777, 897-900).

${ }^{36}$ Murgatroyd (2016) uważa, że Juwenalis nawiązuje tutaj do Verg. Aen. II 254-256: „hic exitus illum / sorte tulit Troiam incensam et prolapsa videntem / Pergama”. Do Juwenalisa, a zapewne też do jego poprzedników, nawiązuje Kochanowski w zakończeniu elegii I 12: „Longa dies Priamo invidit, ne ponere vitam / fortuna posset prosperiore sua. / Huic fert acceptum, quod saeva incendia Troiae / quodque trahi rapidis Hectora vidit equis, / uxorem abduci captivam, sanguine templa / manare atque ipsum caede rubere Iovem" (El. I 12, 55-60). Być może invidit - vidit to zamierzona gra słów (zob. przyp. 42).

${ }^{37}$ Cf. Verg. Aen. XI 159: „felix morte tua” (zob. przyp. 44). 
opłakuje Priama, ale wdowa napomina je, by tego nie robiły i uznały go raczej

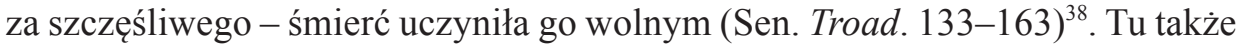
pojawia się odwołanie do zmysłu wzroku - szczęście króla polega na tym, że już nie widzi klęsk, które przynoszą zwycięzcy (149-150: „non ille duos videt Atridas / nec fallacem cernit Ulixem").

Z Troi przenieśmy się teraz do cesarskiego Rzymu i zobaczmy, w jaki sposób Tacyt, pisząc o śmierci swojego teścia Juliusza Agrykoli, stara się pokazać, że umarł on w odpowiednim momencie (Tac. Agr. 45, 3: „tu vero felix, Agricola, non vitae tantum claritate, sed etiam opportunitate mortis") ${ }^{39}$. Agrykola zmarł w sierpniu 93 r., nie dane mu było zatem zaznać błogosławieństwa nowych czasów, kiedy władzę objął najpierw Nerwa (w 96 r.), a potem Trajan (w 98 r. $)^{40}$ - ale, z drugiej strony, zostały mu oszczędzone nieszczęścia ostatnich lat tyrańskich rządów Domicjana. Łaskawej śmierci zawdzięcza Agrykola to, że nieszczęść tych już nie oglądał - non vidit (Tac. Agr. 45, 1):

Non vidit Agricola obsessam curiam et clausum armis senatum et eadem strage tot consularium caedes, tot nobilissimarum feminarum exilia et fugas.

Następuje szczegółowe wyliczenie okropności trzech ostatnich lat rządów Domicjana; Tacyt podkreśla, że to ,my” - pozostali przy życiu - musieliśmy tym okropnościom się przypatrywać, a nawet w jakimś stopniu w nich uczestniczyć (,nostrae duxere Helvidium in carcerem manus”, etc.) ${ }^{41}$. Potem następuje porównanie Domicjana z Neronem $(45,2)$ :

Nero tamen subtraxit oculos suos iussitque scelera, non spectavit: praecipua sub Domitiano miseriarum pars erat videre et aspici, cum suspiria nostra subscriberentur, cum denotandis tot hominum palloribus sufficeret saevus ille vultus, quo se contra pudorem muniebat.

Mamy tu wprawdzie do czynienia - o czym będzie jeszcze mowa - z częstym motywem konsolacyjnym, ale wydaje się, że Tacyt, pisząc o tym, czego Agrykoli udało się już „nie widzieć”, nawiązuje do pierwszych rozdziałów ks. III De oratore Cycerona ${ }^{42}$. Arpinata przedstawia tam ostatnie dni życia

${ }^{38}$, „Felix Priamus» dicite cunctae: / liber manes vadit ad imos” (145-146). Zob. Petrone 2008: 54; Tzounakas 2018: 103-104.

${ }^{39}$ Połączenie opportunitas mortis przed Tacytem występuje tylko u Cycerona (De orat. III 12; Brut. 4), w obu wypadkach odnosząc się do analogicznej co u Tacyta sytuacji - śmierć w stosownym momencie uwalnia od konieczności oglądania nieszczęść (vide infra).

${ }^{40}$ Tac. Agr. 44, 5: ,nam sicut ei <non licuit> durare in hanc beatissimi saeculi lucem ac principem Traianum videre...”., ,Widzieć” oznacza tutaj coś dobrego, w dalszych partiach tekstu już nie.

${ }^{41}$ Słowa historyka w tej części rozdziału 45 pulsują silnymi emocjami. Jak pisze Syme (1958: 25): „Tacitus goes out of his way to make a passionate confession of collective guilt".

${ }^{42}$ Zob. np. Audano 2015: 274-276 (który analizuje interesujący nas motyw w kontekście tematyki konsolacyjnej, odgrywającej ważną rolę zwłaszcza w ostatnich rozdziałach biografii Agrykoli). Innym tekstem Cycerona, do którego Tacyt może się odwoływać, jest Brutus (4: ,illius [...] 
i śmierć jednego z uczestników dialogu, Lucjusza Licyniusza Krassusa. Krassus zmarł we wrześniu 91 r. p.n.e. w stosunkowo młodym wieku (miał 49 lat, cztery lata mniej niż Agrykola w chwili śmierci), ale ten przedwczesny zgon Cyceron skłonny jest postrzegać jako dar bogów (Cic. De orat. III 8):

Fuit hoc luctuosum suis, acerbum patriae, grave bonis omnibus; sed ii tamen rem publicam casus secuti sunt, ut mihi non erepta L. Crasso a dis immortalibus, sed donata mors esse videatur. Non vidit flagrantem bello Italiam, non ardentem invidia senatum, non sceleris nefarii principes civitatis reos, non luctum filiae, non exilium generi, non acerbissimam C. Mari fugam, non illam post reditum eius caedem omnium crudelissimam, non denique in omni genere deformatam eam civitatem, in qua ipse florentissima multum omnibus gloria praestitisset.

W tym zdaniu - znacznie dłuższym niż analogiczne zdanie w Żywocie Agrykoli - zwraca uwagę, oprócz wielokrotnego powtórzenia partykuły non, także podkreślenie swoistej symbiozy między Krassusem a rzymskim państwem; jest zrozumiałe, że gdy państwo to uległo deprawacji, dla Krassusa nie ma już miejsca wśród żywych. Podobnie jak Tacyt, Cyceron w dalszej części bardziej szczegółowo wylicza nieszczęścia, które dotknęły Rzymian po roku 91 - i których widoku bogowie oszczędzili Krassusowi; wspomina m.in. o zabiciu dwóch innych uczestników dialogu, Marka Antoniusza i Cezara Strabona - ich odcięte głowy wystawiono na widok publiczny na rostrach ${ }^{43}$. I - znowu podobnie jak Tacyt - wyliczenie to kończy apostrofą do zmarłego: „ego vero te, Crasse, cum vitae flore tum mortis opportunitate divino consilio et ornatum et extinctum esse arbitror" (III 12)

Niemal trzysta lat po Tacycie św. Hieronim pisze list, w którym pociesza biskupa Heliodora po śmierci siostrzeńca Nepocjana. List Hieronima

mortis opportunitatem benevolentia potius quam misericordia prosequamur”, zob. przyp. 39; 329: „sed fortunatus illius exitus, qui ea non vidit cum fierent, quae providit futura" - w obu wypadkach chodzi o mówcę Hortensjusza, który zmarł w 49 r., unikając w ten sposób nieszczęść wojny domowej i dyktatury Cezara).

${ }^{43}$ Działo się to w 87 r. podczas czystek przeprowadzanych przez Mariusza i Cynnę. Ironią historii jest, że 44 lata później na tych samych rostrach eksponowano głowę Cycerona - zabitego z rozkazu wnuka tegoż mówcy, Antoniusza. Warto odnotować, że Liwiusz, pisząc o wydarzeniach z grudnia 43 r. (Liv. fr. 50 Weissenborn = Sen. Rhet. Suas. 6, 17) zapewne wzorował się na passusie z De oratore III 10 o Antoniuszu seniorze; zob. Degl'Innocenti Pierini 2003: 26.

${ }^{44} \mathrm{~W}$ związku z frazą opportunitas mortis zob. przyp. 39. Zarówno kolejność poszczególnych elementów - (1) zdanie z non vidit, (2) szczegółowa enumeracja nieszczęść, (3) apostrofa z frazą opportunitas mortis - jak i konstrukcja samej tej apostrofy (Cic.: „cum vitae flore tum mortis opportunitate” $\sim$ Tac.: ,non vitae tantum claritate, sed etiam opportunitate mortis”) wskazują bardzo wyraźnie, że Tacyt w Agr. 45, 1-3 nawiązuje przede wszystkim do De orat. III 8-12. Badacze zauważają też związek między apostrofą do Agrykoli u Tacyta a słowami Ewandra z Eneidy, który nad zwłokami swego syna Pallasa przywołuje zmarłą żonę: ,tuque, o sanctissima coniunx, felix morte tua neque in hunc servata dolorem!" (Verg. Aen. XI 158-159); zob. np. Soverini 2004: 308 oraz Woodman, Kraus 2014: 320. Warto pamiętać, że apostrofa do zmarłego to częsty element rzymskiej mowy pogrzebowej, a ostatnie rozdziały Żywotu Agrykoli wykazują liczne związki z laudatio funebris. 
w interesujący sposób pokazuje, jak autorzy chrześcijańscy adaptują - zgodnie z zasadą określaną jako chresis - pogańską topikę konsolacyjną, uzupełniając ją argumentacją odnoszącą się do nowej religii i właściwego jej świata pojęciowego $^{45}$. Zbliżając się do końca listu, autor kreśli dramatyczny obraz świata, w którym jemu i adresatowi przyszło żyć (Hier. Epist. 60, 16, 2-3):

...horret animus temporum nostrorum ruinas prosequi. Viginti et eo amplius anni sunt quod inter Constantinopolim et Alpes Iulias cotidie Romanus sanguis effunditur. [...] Capti episcopi, interfecti presbyteri et diversorum officia clericorum, subversae ecclesiae, ad altaria Christi stabulati equi, martyrum effosae reliquiae; ubique luctus, ubique gemitus et plurima mortis imago ${ }^{46}$.

Jeszcze przez kilkanaście wierszy odmalowuje Hieronim ogrom udręk swoich czasów, po czym reflektuje się, stwierdzając, że nie zamierza przecież pisać dzieła historycznego; chce tylko „krótko opłakać nasze nieszczęścia” $(60,16,5)$. Ale w obliczu tych nieszczęść nawet Tukidydes i Salustiusz musieliby zamilknąć. I teraz następują takie słowa $(60,17,1)$ :

Felix Nepotianus, qui haec non videt; felix, qui ista non audit. Nos miseri, qui aut patimur aut patientes fratres nostros tanta perspicimus; et tamen vivere volumus, eosque qui his carent flendos potius quam beandos putamus.

Nie ma powodu zakładać, że Hieronim, pisząc te słowa, miał na podorędziu De oratore Cycerona bądź biografię Agrykoli. Posługuje się bowiem toposem konsolacyjnym, w tej czy innej postaci odnajdywanym w wielu tekstach. Nie zawsze jednak, gdy mowa o nieszczęściach, które zmarłemu - najczęściej przedwcześnie zmarłemu, jak tutaj ów siostrzeniec biskupa - zostały oszczędzone, pojawia się odwołanie do zmysłu wzroku; nie zawsze zostaje podkreślone to, że zmarły nie musi już oglądać tych udręk, których my, pozostali przy życiu, jesteśmy świadkami (Hieronim do zmysłu wzroku dodaje jeszcze zmysł słuchu) ${ }^{47}$.

${ }^{45}$ Zob. na ten temat Scourfield 1993: 15-33 i passim.

${ }^{46}$ Ten silnie zretoryzowany passus wzmacniają dodatkowo kryptocytaty z ks. II Eneidy (12: „quamquam animus meminisse horret luctuque refugit”; 368-369: „crudelis ubique / luctus, ubique pavor et plurima mortis imago"). Potem jest jeszcze cytat z Aen. VI 625-627 $(60,16,5)$. Klęski dotykające świat rzymski pod koniec IV w. stylizuje Hieronim na upadek Troi; podobnie postąpił dobrze znany Hieronimowi Pliniusz Młodszy, opisując wybuch Wezuwiusza (Plin. Epist. VI 20; zob. Schwerdtner 2015: 147-161).

${ }^{47}$ Zob. Kassel 1958: 82; Esteve-Forriol 1962: 152; Scourfield 1993: 198-199 (liczne przykłady z autorów pogańskich i chrześcijańskich). Z tekstów, w których ten topos występuje bez odwołania do zmysłu wzroku, wymieńmy: Sulpicius ap. Cic. Fam. IV 5, 5 (Serwiusz Sulpicjusz pociesza Cycerona po śmierci Tulii); Stat. Silv. II 1, 220-226 (z podobnym jak u Hieronima przeciwstawieniem „hic quem gemimus felix” / „nos miseri”); [Plut.] Cons. ad Apoll. 35 [= Mor. 119F]. Przywołajmy jeszcze postać naszego Jana z Czarnolasu, który w Trenie XIX pisze tak: „Nie od rozkoszyć poszła; poszłać od trudności / Od pracej, od frasunków, od złez, od żałości..." (5152 i dalej, do w. 64). Kochanowski, podobnie jak autor Pocieszenia do Apolloniosa, wspomina 
Przytoczmy urywek jednego jeszcze utworu konsolacyjnego, gdzie motyw ten zostaje wprowadzony, przy czym - inaczej niż w wypadku Nepocjana (oraz Krassusa, Hortensjusza i Agrykoli) - padają a contrario przykłady osób, które nie umarły „w stosownym czasie”. Tym utworem jest Pocieszenie dla Marcji Seneki; pociesza ją filozof po śmierci syna, zmarłego w młodym wieku - znów jest to więc mors immatura. W rozdz. 20 Seneka zwraca się do Marcji słowami: "Cogita, quantum boni opportuna mors habeat, quam multis diutius vixisse nocuerit” (Sen. Cons. ad Marc. 20, 4). A zatem jesteśmy w wątku refleksji, które snuł Cyceron w ks. I Rozmów tuskulańskich. Seneka przytacza trzy przykłady - Pompejusza (cf. Cic. Tusc. I 86), samego Cycerona ${ }^{48}$ i Katona Młodszego. Ograniczmy się do środkowego $(20,5)$ :

M. Cicero si illo tempore, quo Catilinae sicas devitavit, quibus pariter cum patria petitus est, concidisset, liberata re publica servator eius, si denique filiae suae funus secutus esset, etiamnunc felix mori potuit ${ }^{49}$. Non vidisset strictos in civilia capita mucrones nec divisa percussoribus occisorum bona, ut etiam de suo perirent, non hastam consularia spolia vendentem nec caedes nec locata publice latrocinia, bella, rapinas, tantum Catilinarum ${ }^{50}$.

Powróćmy do Żywotu Agrykoli i przedstawionej tam synkrisis Domicjana z Neronem (Tac. Agr. 45, 2). Wynikałoby z niej, że pod pewnymi względami Neron nie był tak okrutnym władcą jak Domicjan: owszem, inicjował czyny zbrodnicze, ale sam się im nie przyglądał (,iussitque scelera, non spectavit”). Oglądanie własnych zbrodni i czerpanie przyjemności z takiego widoku należy do standardowego zestawu zachowań przypisywanych tyranom. Przywołajmy, tytułem przykładu, Hannibala, który - wedle przekazu Seneki - miał zawołać na widok rowu pełnego krwi: „o formosum spectaculum!”51. Albo Marka Antoniusza, który wpatrywał się w odciętą głowę i rękę Cycerona, wybuchając

o nieszczęściach, które są immanentnie związane z kondycją ludzką (cf. słowa Artabanosa do Kserksesa u Herodota VII 46); inaczej Cyceron, Tacyt czy Hieronim, którzy eksponują udręki spadające na ludzi z zewnątrz, zwykle wynikające ze zmienionej sytuacji politycznej. Tylko w tym drugim wypadku można zasadnie mówić o opportunitas mortis.

${ }^{48}$ Tu również mógł się Seneka inspirować Rozmowami tuskulańskimi. Cyceron, zanim wprowadzi exempla Priama i Pompejusza, mówi krótko o własnym doświadczeniu (Cic. Tusc. I 84).

${ }^{49}$ Dość to ryzykowna opinia, jeśli weźmie się pod uwagę, jak wielkim ciosem była dla Cycerona śmierć Tulii. Można powiedzieć, że Seneka redukuje tu Cycerona do roli polityka; liczy się tylko chwała udaremnienia spisku Katyliny i nędza proskrypcji $43 \mathrm{r}$.

${ }^{50}$ Zmysł wzroku przywołuje Seneka także w związku z Pompejuszem, i to dwukrotnie: ,vidit legiones in conspectu suo caesas” oraz, kilka wierszy potem, „vidit Aegyptium carnificem...” $(20,4)$. Czy to anaforyczne vidit jest jakąś delikatną aluzją do Enniusza i Wergiliusza, piszących o śmierci Priama? Zob. przyp. 33 oraz Sen. Ag. 656.

${ }^{51}$ Sen. De ira II 5, 4. Warto przytoczyć komentarz Seneki, sformułowany jako apostrofa do Hannibala: „Quid mirum, si hoc maxime spectaculo caperis, innatus sanguini et ab infante caedibus admotus? Sequetur te fortuna crudelitati tuae per viginti annos secunda dabitque oculis tuis gratum ubique spectaculum; videbis istud et circa Trasumennum et circa Cannas et novissime circa Carthaginem tuam". Zob. Backhaus 2019: 161-164. 
wielokrotnie śmiechem (Plut. Ant. 20, 2) ${ }^{52}$. Przeciwstawienie w tym względzie Nerona Domicjanowi jest jednak problematyczne. Autorowi Żywotu Agrykoli zależy na tym, by ukazać Domicjana - stanowiącego negatywny kontrast dla bohatera biografii - w jak najciemniejszych barwach; prowadzi go to tutaj do częściowego, nieuzasadnionego „wybielenia” wcześniejszego władcy. Sam bowiem historyk dwie dekady później w Rocznikach dostarcza przykładów na to, że Neron bynajmniej nie „odwracał swoich oczu” od nakazanych przez siebie zbrodni, że z lubością przyglądał się - podobnie jak Marek Antoniusz - odciętym głowom swoich politycznych przeciwników czy okrutnym egzekucjom ${ }^{53}$.

Należy podkreślić, że w $A g r .45,2$ motyw patrzenia użyty jest w trzech różnych wariantach. Najpierw (non spectavit) chodzi o samego cesarza, znajdującego przyjemność w oglądaniu zbrodni - lub odwracającego wzrok, jak robił to rzekomo Neron. Potem jednak autor przenosi swoją uwagę na poddanych, których dodatkową udręką staje się to, że muszą sami przyglądać się okrucieństwom władcy (videre). Odpowiada to temu, co Tacyt pisał na początku tego rozdziału o swoim teściu, którego śmierć w sierpniu $93 \mathrm{r}$. uchroniła go od widoku „oblężonej kurii, senatu obstawionego zbrojnym wojskiem, dokonanej równocześnie rzezi tylu byłych konsulów, wygnania tylu znakomitych niewiast”. Ale jest jeszcze trzeci wariant tego motywu - poddani nie tylko muszą patrzeć, ale sami także są oglądani (aspici). Chodzi tu oczywiście o to, jak reagują na widok zbrodni, czy okazują jakieś emocje, wykonują jakieś gesty, które mogłyby zostać zinterpretowane jako krytyka okrutnych działań cesarza. Oglądani są bądź przez samego władcę, bądź przez jego zaufanych pomocników.

Poddani mogą być zresztą zmuszani do przypatrywania się nie tylko zbrodniom. Można ich także zmusić do oglądania występów scenicznych cesarza. W ten sposób znów wracamy do Nerona - i znów okazuje się, że zaproponowana przez Tacyta synkrisis tego władcy z Domicjanem nie znajduje potwierdzenia w przekazach historycznych. Swetoniusz w biografii Nerona pisze bowiem tak (Suet. Nero 23, 2):

Cantante eo ne necessaria quidem causa excedere theatro licitum est. Itaque et enixae quaedam in spectaculis dicuntur et multi taedio audiendi laudandique clausis oppidorum portis aut furtim desiluisse de muro aut morte simulata funere elati.

${ }^{52}$ Dopiero potem zostały one wystawione na widok publiczny (cf. przyp. 43). Jak pisze Plutarch w innym miejscu (Plut. Cic. 49, 1), dla Rzymian był to widok pełen grozy $(\theta \dot{\varepsilon} \alpha \mu \alpha[\ldots]$

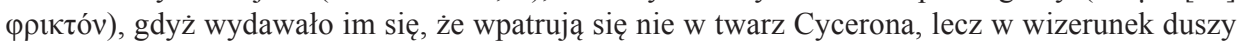
Antoniusza.

${ }^{53}$ Zob. Tac. Ann. XIV 57, 4 (głowa Korneliusza Sulli); 59, 3 (głowa Rubelliusza Plauta; cf. Cass. Dio LXII 14, 1, który przytacza słowa cesarza: „nie wiedziałem, że miał taki duży nos”); XV 44, 5 (katusze i egzekucje chrześcijan oskarżonych o podpalenie Rzymu). Zob. też XIV 9, 1 (według niektórych przekazów Neron oglądał zabitą Agrypinę i chwalił jej urodę); XIV 64, 2 (Poppea Sabina przyglądała się odciętej głowie Oktawii). 
Również Kasjusz Dion podaje, że widzowie, chcąc opuścić teatr, musieli udawać, że zemdleli lub umarli - wtedy ich wynoszono (Cass. Dio LXIII 15, 3). Tacyt z kolei wspomina o ludziach, którzy faktycznie - zmuszeni do siedzenia dniami i nocami w teatrze - zapadali na śmiertelne choroby (Tac. Ann. XVI 5, 3). Jak zauważa Shadi Bartsch, w Rzymie Nerona widzowie w teatrze sami stawali się aktorami - odgrywając własną śmierć (cf. morte simulata u Swetoniusza) bądź po prostu udając entuzjazm na widok Nerona występującego na scenie jako Orestes lub rodząca Kanake ${ }^{54}$. Tacyt mówi także o ludziach na widowni, których zadaniem było bacznie obserwować reakcję publiczności: „ut nomina ac voltus, alacritatem tristitiamque coeuntium scrutarentur".

Mamy więc tutaj równocześnie (cf. videre et aspici) przymus oglądania i świadomość bycia oglądanym; konsekwencje „niewłaściwego” zachowania widza mogły być bardzo poważne ${ }^{55}$. Teatralność, co dobrze pokazuje Tacyt w Rocznikach, dotyczyła zresztą różnych sfer życia, nie tylko widowisk ${ }^{56}$. Rola patrzenia, obserwowania, jak kto się w danej sytuacji zachowuje, zostaje uwydatniona (by ograniczyć się do jednego przykładu) w scenie śmierci Brytanika. Syn Klaudiusza już został otruty; teraz Tacyt skupia swoją uwagę na tym, jak zachowują się świadkowie tego zdarzenia (Tac. Ann. XIII 16, 3-4):

Trepidatur a circumsedentibus, diffugiunt imprudentes: at quibus altior intellectus, resistunt defixi et Neronem intuentes. [...] At Agrippinae is pavor, ea consternatio mentis, quamvis vultu premeretur, emicuit, ut perinde ignaram fuisse atque Octaviam sororem Britannici constiterit [...]. Octavia quoque, quamvis rudibus annis, dolorem caritatem, omnis adfectus abscondere didicerat.

A zatem tylko imprudentes działają spontanicznie; ci rozsądni wpatrują się w cesarza - co on zrobi, co powie. Agrypinie nie do końca udało się ukryć

\footnotetext{
${ }^{54}$ Bartsch 1994: 10: „For Tacitus, Dio, and Suetonius, Nero's rule is the occasion for a transformation of a theater into the site of a reversal of actor-audience relations, and as an emperor onstage, Nero literally constrained his audience to be actors”. Rodząca Kanake jako jedna z ról Nerona: Cass. Dio LXIII 10, 2. Wspominam o niej dlatego, że rysuje się tu ciekawa analogia do wzmiankowanych przez Swetoniusza kobiet na widowni, które tym razem nie grały, lecz faktycznie rodziły w teatrze, nie mogąc go opuścić.

${ }^{55}$ Tacyt podaje przykład Wespazjana, któremu zdarzyło się przysnąć podczas występu Nerona (Tac. Ann. XVI 5, 6; cf. Suet. Vesp. 4, 4) - tylko dzięki wstawiennictwu przyjaciół udało mu się wyjść z tego obronną ręką. Mniej szczęścia miał anonimowy pater familias za Domicjana, który ośmielił się wyrazić inną niż cesarz opinię o pojedynku gladiatorów (Suet. Dom. 10, 1: „detractum spectaculis in harenam canibus obiecit" - a zatem z widza stał się częścią widowiska). To zupełnie inna sytuacja niż ta, o której pisał Owidiusz: „spectatum veniunt, veniunt spectentur ut ipsae” (Ov. Ars I 99).

${ }^{56}$ Oczywiście należy pamiętać o tym, jak wielką rolę odgrywała w rzymskiej kulturze i życiu społecznym widowiskowość - poza widowiskami w ścisłym tego słowa znaczeniu (teatralnymi, gladiatorskimi czy cyrkowymi). Terminem spectaculum można było określać pochody triumfalne, pogrzeby, przybycie władcy po długiej nieobecności do miasta (adventus), egzekucje przestępców itp.
} 
emocje; Oktawia, choć znacznie młodsza, okazała się bardziej pojętną uczennicą (didicerat) ${ }^{57}$. Mimo że historyk nie mówi o tym wprost, to z jego opisu wynika jasno, że tak jak inni obserwowali Nerona, tak on - samodzielnie lub przy pomocy wtajemniczonych osób - bacznie obserwował zachowanie matki i żony.

Przyjrzyjmy się jeszcze na koniec, w jaki sposób motyw oglądania (lub bycia oglądanym) jako dodatkowej udręki może funkcjonować w odniesieniu do osób, którym wymierza się karę. Lukan w ks. II Wojny domowej wprowadza postać sędziwego mieszkańca Rzymu; on to w obliczu zbliżającego się konfliktu Cezara z Pompejuszem wspomina tragiczne wydarzenia, których był świadkiem jakieś czterdzieści lat wcześniej. Szczegółowo opisuje śmierć Mariusza Gratidianusa (siostrzeńca Gajusza Mariusza), zabitego po zwycięstwie Sulli. Gratidianus umierał powoli - o to właśnie chodziło, by długo cierpiał - gdy odcinano mu kolejno ręce, język, uszy i nos. Lukan podkreśla, że oczy wyłupiono mu dopiero na samym końcu (Lucan. II 181-185):

Avolsae cecidere manus, exsectaque lingua
palpitat et muto vacuum ferit aera motu.
Hic aures, alius spiramina naris aduncae
amputat; ille cavis evolvit sedibus orbes
ultimaque effodit spectatis lumina membris.

Śmierć Gratidianusa znana jest nam z innych przekazów, w których również mowa jest o tym, że zanim umarł, był okrutnie kaleczony, także przez wyłupienie oczu. Ale tylko Lukan przedstawia to tak, że oślepiono go dopiero na końcu - właśnie po to, by musiał oglądać, jakie tortury się mu zadaje ${ }^{58}$.

Drugi przykład dotyczy egzekucji cesarza Witeliusza po zdobyciu Rzymu przez wojska flawijskie pod koniec grudnia 69 r. n.e. Mamy trzy dość dokładne opisy ostatnich chwil cesarza, różniące się ciekawymi detalami (chronologicznie: Tac. Hist. III 84, 4-85; Suet. Vit. 16-17; Cass. Dio LXV 20-21). Swetoniusz pisze o tym, że gdy prowadzono Witeliusza ulicami Rzymu na miejsce egzekucji, podkładano mu pod brodę ostrze miecza - tak by nie opuszczał twarzy, lecz

${ }^{57}$ Cf. Tac. Ann. VI 45, 3: „simulationum [...] falsa in sinu avi perdidicerat” (o Kaliguli; dziadek to Tyberiusz). Bartsch (1994: 14) zwraca uwagę na to, że choć śmierć Brytanika opisują także Swetoniusz i Kasjusz Dion, tylko u Tacyta występuje motyw gry (przejawiającej się m.in. w tym, jakie emocje są okazywane na zewnątrz, a jakie tłumione) i obserwowania zachowań uczestników zdarzenia. Dobrą analizę teatralnych aspektów narracji Tacyta o śmierci Brytanika przedstawia Schmitzer (2005). W tym kontekście warto przywołać Powrót prokonsula Zbigniewa Herberta, a zwłaszcza słowa „nie spuszczać oka z Tacyta”.

${ }^{58}$ Zob. Fantham 1992: 112-114. Zauważmy na marginesie (bo wiąże się to z tematem tego artykułu), że Waleriusz Maksymus, wspominając śmierć Gratidianusa, dodaje, że zaraz potem Sulla kazał zabić Marka Pletoriusza - za to że zemdlał, gdy był świadkiem tamtej egzekucji (,,.. continuo ibi mactavit, novus punitor misericordiae, apud quem iniquo animo scelus intueri scelus admittere fuit”); Val. Max. IX 2, 1. Zresztą cały rozdział Waleriusza O okrucieństwie zasługiwałby na naszą uwagę (np. 4: żony zabijane na oczach mężów, dzieci na oczach rodziców). 
by można ją było zobaczyć (,ut visendam praeberet faciem neve summitteret”, 17, 1). Witeliusz jest więc, jak to sformułował z kolei Tacyt, „,foedum spectaculum" (III 84, 5) ${ }^{59}$. Ale Tacyt, który też wspomina o ostrzach mieczy, dodaje coś jeszcze: żołnierze Wespazjana zmuszali go w ten sposób nie tylko do tego, by swoją twarz wystawił na zniewagi, ale też do tego, by sam był obserwatorem (III 85):

Vitellium infestis mucronibus coactum modo erigere os et offerre contumeliis, nunc cadentes statuas suas, plerumque rostra aut Galbae occisi locum contueri, postremo ad Gemonias, ubi corpus Flavii Sabini iacuerat, propulere.

Można powiedzieć, że żołnierze zmuszają cesarza do odbycia spaceru ulicami Rzymu, połączonego ze zwiedzaniem miejsc, które w historii jego krótkiego panowania były symbolicznie ważne ${ }^{60}$. Witeliusz jest zatem przedmiotem widowiska i widzem równocześnie (cf. „videre et aspici”).

Tematu nie da się wyczerpać w jednym artykule, a teksty, które zasługiwałyby na analizę, można by mnożyćc ${ }^{61}$. W zakończeniu przywołajmy raz jeszcze Opowieść etiopska Heliodora. Królowa etiopska Persinna, matka Chariklei, w trakcie miłosnego zbliżenia ze swoim mężem spojrzała na obraz przedstawiający białą Andromedę - i dlatego jej córka urodziła się biała (po czym została porzucona, gdyż matka obawiała się, że zostanie posądzona o cudzołóstwo $)^{62}$. Dionizjusz z Halikarnasu w zachowanym fragmentarycznie traktacie $O$ naśladowaniu

${ }^{59}$ Warto przytoczyć ten poruszający passus: „vinctae pone tergum manus; laniata veste, foedum spectaculum, ducebatur, multis increpantibus, nullo inlacrimante: deformitas exitus misericordiam abstulerat". Tacyt nawiązuje tutaj do wcześniejszego epizodu, zwiedzania przez Witeliusza pola bitwy pod Bedriakum (gdzie czterdzieści dni wcześniej jego wojsko pokonało armię Othona); pobojowisko zostało określone jako „foedum atque atrox spectaculum” (II 70, 1). Również w innych miejscach Witeliusz przedstawiany jest jak tyran, który syci swoje oczy widokiem własnych zbrodni (zob. np. Keitel 2007). Teraz następuje odwrócenie ról - to on sam staje się widowiskiem (cf. przyp. 55). Nie rozwijam tego tematu, bo przedstawiłem go dość obszernie w innym miejscu (Pigoń 2004: 108-123).

${ }^{60}$ Śmierć cesarza Galby (zabitego w styczniu 69 r. przez pretorianów, którzy przeszli na stronę Othona) oznaczała dla Witeliusza, że odtąd jego głównym przeciwnikiem będzie Othon; Witeliusz początkowo wystąpił jako uzurpator przeciw Galbie. Flawiusz Sabinus, brat Wespazjana, został zabity kilka dni przed zdobyciem Rzymu przez wojska flawijskie - tę egzekucję zresztą Witeliusz próbował bezskutecznie powstrzymać (Tac. Hist. III 74, 2). Kasjusz Dion, podobnie jak Tacyt, podaje, że ,gdy [Witeliusz] ogarnięty wstydem opuszczał wzrok, żołnierze kłuli go w brodę sztyleta-

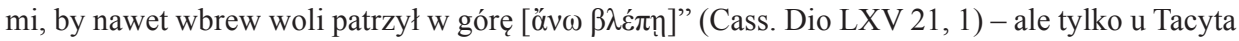
mowa jest o tym, co Witeliusz, przymuszony do podniesienia wzroku, oglądał.

${ }^{61} \mathrm{Na}$ zasadzie praeteritio wskazałbym tylko na ostatnią scenę Medei Seneki: tytułowa bohaterka zabija drugiego syna dopiero wtedy, gdy pojawia się Jazon; mówi: „derat hoc unum mihi, / spectator iste” (Sen. Med. 992-993); cf. Verg. Aen. X 443: „,cuperem ipse parens spectator adesset” (Turnus zabijający Pallasa). Na temat roli przyglądania się (Zusehen) w konstruowanych w tragediach Seneki „strategiach zemsty” zob. Winter 2014: 115-179.

${ }^{62}$ Heliod. IV 8; cf. X 14-15. Zob. Whitmarsh 2002. 
przytacza anegdotę mogącą zainspirować Heliodora. Oto szpetny z wyglądu rolnik obawiał się, że jego dzieci też będą pozbawione urody. Dlatego zaopatrzył się w piękne obrazy i kazał swojej żonie się im przyglądać. Dzieci, które potem płodził, rzeczywiście rodziły się piękne jak te obrazy. Dla Dionizjusza to dobra ilustracja tego, jak przestawanie z wielkimi dziełami dawnych autorów może kształtować naszą własną twórczość ${ }^{63}$.

W tekstach, które omawialiśmy w tym artykule, patrzenie nie ma zapewne takiej siły sprawczej, jak w historiach opowiedzianych przez Heliodora i Dionizjusza. Jest natomiast na pewno przeżyciem traumatycznym, pozostawiającym w duszy obserwatora trwałe ślady. Eneasz widział zagładę Troi i śmierć Priama i nawet po upływie siedmiu lat nie ma szczególnej ochoty, by wracać do tamtych wydarzeń (Verg. Aen. II 3: „infandum, regina, iubes renovare dolorem”). Zasadna wydaje się opinia, że właśnie emocjonalny ładunek zawarty w opisach, w których podkreślona została perspektywa widza wewnątrztekstowego obserwatora zaangażowanego - jest jednym z czynników, które sprawiają, iż czytając dzieła Wergiliusza, Seneki czy Tacyta mamy świadomość obcowania z prawdziwą literaturą.

\section{BIBLIOGRAFIA}

\section{Źródła, przekłady, komentarze}

Cornelio Tacito, Agricola, introduzione, testo critico, traduzione e commento a cura di P. Soverini, Alessandria 2004 [= Soverini 2004].

E. Courtney, A Commentary on the Satires of Juvenal, London 1980.

Ennius, The Tragedies. The Fragments, ed. by H.D. Jocelyn, Cambridge 1969 [= Jocelyn 1969]. Eurypides, Tragedie, t. II: Andromacha, Oszalaty Herakles, Trojanki, Elektra, Ifigenia w kraju Taurów, Ijon, przeł. J. Łanowski, przekład przejrzała J. Ławińska-Tyszkowska, wyd. II, Warszawa 2006.

Heliodor, Opowieść etiopska o Theagenesie i Chariklei, przekł., wstęp i oprac. S. Dworacki, Poznań 2000.

Lucan, De Bello Civili, Book II, ed. by E. Fantham, Cambridge 1992 [= Fantham 1992].

J.H.D. Scourfield, Consoling Heliodorus. A Commentary on Jerome, Letter 60, Oxford 1993.

Tacitus, Agricola, ed. by A.J. Woodman, with Contributions from C.S. Kraus, Cambridge 2014 [= Woodman, Kraus 2014].

\section{Opracowania}

Audano 2015: S. Audano, Sopravvivere senza l'adilà. La consolatio laica di Tacito nell'Agricola, w: Le parole dopo la morte. Forme e funzioni della retorica funeraria nella tradizione greca e romana, red. C. Pepe, G. Moretti, Trento 2015, 245-288.

Backhaus 2019: M. Backhaus, Mord(s)bilder-Aufzahlungen von Gewalt bei Seneca und Lucan, Berlin-Boston 2019.

Bal 2012: M. Bal, Narratologia. Wprowadzenie do teorii narracji, Kraków 2012.

${ }^{63}$ Don. Hal. De imit. fr. 6, pp. 203 Usener-Radermacher. Zob. Hunter 2009: 107-127. Na zbieżność między Heliodorem a Dionizjuszem zwraca uwagę Whitmarsh (2002: 115). 
Bartsch 1994: S. Bartsch, Actors in the Audience. Theatricality and Doublespeak from Nero to Hadrian, Cambridge, MA-London 1994.

Ben-Porat 1988: Z. Ben-Porat, Poetyka aluzji literackiej, przeł. M. Adamczyk-Garbowska, „Pamiętnik Literacki” LXXIX/1 (1988), 315-337.

Berno 2004: F.R. Berno, Un truncus, molti re. Priamo, Agamennone, Pompeo (Virgilio, Seneca, Lucano), „Maia” LVI (2004), 79-84.

Bowie 1990: A.M. Bowie, The Death of Priam: Allegory and History in the Aeneid, „Classical Quarterly"XL (1990), 470-481.

Brena 1993: F. Brena, Das Blut und die Flamme. Anmerkung zu Lucan 2, 126-129, „Rheinisches Museum" CXXXVI (1993), 307-321.

Briggs 1980: W.W. Briggs, Jr., Narrative and Simile from the Georgics in the Aeneid, Leiden 1980.

Bühler 1976: W. Bühler, Das Element des Visuellen in der Eingangsszene von Heliodors Aithiopika, „Wiener Studien” LXXXIX (1976), 177-185.

Degl'Innocenti Pierini 2003: R. Degl'Innocenti Pierini, Cicerone nella prima età imperiale. Luci ed ombre su un martire della repubblica, w: Aspetti della fortuna di Cicerone nella cultura latina. Atti del III Symposium Ciceronianum Arpinas, Arpino 10 maggio 2002, red. E. Narducci, Firenze 2003, 3-54.

Dworacki 1996: S. Dworacki, Theatre and Drama in Heliodorus' Aethiopika, „Eos” LXXXIV (1996), 355-361.

Elliott 2008: J. Elliott, Ennian Epic and Ennian Tragedy in the Language of the Aeneid. Aeneas' Generic Wandering and the Construction of the Latin Literary Past, „Harvard Studies in Classical Philology" CIV (2008), 241-272.

Esteve-Forriol 1962: J. Esteve-Forriol, Die Trauer- und Trostgedichte in der römischen Literatur untersucht nach ihrer Topik und ihrem Motivschatz, diss. München 1962.

Genette 1972: G. Genette, Figures III, Paris 1972.

Hunter 2009: R. Hunter, Critical Moments in Classical Literature. Studies in the Ancient View of Literature and its Uses, Cambridge 2009.

de Jong 1987: I.J.F. de Jong, Narrators and Focalizers: The Presentation of the Story in the Iliad, Amsterdam 1987.

de Jong 2014: I.J.F. de Jong, Narratology and Classics: A Practical Guide, Oxford 2014.

Kassel 1958: R. Kassel, Untersuchungen zur griechischen und römischen Konsolationsliteratur, München 1958.

Keitel 2007: E. Keitel, Feast Your Eyes on This: Vitellius as a Stock Tyrant (Tac. Hist. 3.36-39), w: A Companion to Greek and Roman Historiography, red. J. Marincola, Malden 2007, 441446.

Knox 1950: B.M.W. Knox, The Serpent and the Flame: The Imagery of the Second Book of the Aeneid, „American Journal of Philology” LXXI (1950), 379-400.

Lee 1979: M.O. Lee, Fathers and Sons in Virgil's Aeneid: tum genitor natum, Albany 1979.

Lohikoski 1966: K.K. Lohikoski, Der Parallelismus Mykene-Troja in Senecas „Agamemnon”, „Arctos” IV (1966), 63-70.

Murgatroyd 2016: P. Murgatroyd, Juvenal, Virgil and the Death of Priam, „Latomus” LXXV (2016), 183-186.

O'Sullivan 2009: T.M. O'Sullivan, Death ante ora parentum in Virgil's Aeneis, „Transactions of the American Philological Association" CXXXIX (2009), 447-486.

Petrone 2008: G. Petrone, La "fragile fortuna" di Priamo e Pompeo. Uno schema tragico d'interpretazione, „Maia” LX (2008), 51-63.

Pigoń 2004: J. Pigoń, Ze studiów nad technikami narracyjnymi Tacyta. Wypowiedzi proleptyczne, Wrocław 2004.

Rivoltella 2005: M. Rivoltella, Le forme del morire. La gestualità nelle scene di morte dell'Eneide, Milano 2005. 
Schmitzer 2005: U. Schmitzer, Der Tod auf offener Szene. Tacitus über Nero und die Ermordung des Britannicus, „Hermes” CXXXIII (2005), 337-357.

Scholes, Kellogg 1966: R. Scholes, R. Kellogg, The Nature of Narrative, Oxford 1966.

Schwerdtner 2015: K. Schwerdtner, Plinius und seine Klassiker. Studien zur literarischen Zitation in den Pliniusbriefen, Berlin-Boston 2015.

Stabryła 1970: S. Stabryła, Latin Tragedy in Virgil’s Poetry, Wrocław 1970.

Stahl 1981: H.-P. Stahl, Aeneas - an „Unheroic” Hero?, „Arethusa” XIV (1981), 157-177.

Syme 1958: R. Syme, Tacitus, Oxford 1958.

Telò 2011: M. Telò, The Eagle's Gaze in the Opening of Heliodorus' Aethiopica, „American Journal of Philology" CXXXII (2011), 581-613.

Tzounakas 2018: S. Tzounakas, Seneca's Hecuba and Lucan's Cornelia, „Pan” VII (2018), 95112.

Whitmarsh 1992: T. Whitmarsh, Written on the Body: Ekphrasis, Perception and Deception in Heliodorus' Aethiopica, „Ramus” XXXI (2002), 111-125.

Wigodsky 1972: M. Wigodsky, Vergil and Early Latin Poetry, Wiesbaden 1972.

Winter 2014: K. Winter, Artificia mali. Das Böse als Kunstwerk in Senecas Rachetragödien, Heidelberg 2014.

\section{SIGHT AND SUFFERING: FROM THE ROMAN HISTORY OF A LITERARY MOTIF}

\section{Sum mary}

In Roman literature, characters within the text are often shown as emotionally engaged viewers; viewing may be connected with mental or emotional suffering. The paper examines a number of passages in which sight and suffering are closely linked. In Roman narratives of the fall of Troy, for example, such characters as Andromache, Priam, Hecuba or Aeneas are represented as watching the destruction of the city and the killing of their loved ones; emphasis is laid on their emotional response to what they are seeing. The evolution of the motif from Ennius through Cicero, Vergil, Ovid and Seneca the Younger to Juvenal is sketched and discussed. The paper examines also the role of viewing in consolatory contexts. In such works as Tacitus' Agricola or Jerome's Epistles 60 , someone's premature death is shown as advantageous because the dead person is now spared the necessity of watching misfortunes, usually relating to the political sphere, which the living have to witness. Another common idea is that of people being forced, e.g. by an emperor, to watch something unpleasant, evil or cruel; in such a situation they are usually viewers and objects of viewing at the same time, since their gestures and facial expression are carefully observed and may be used against them. Tacitus' account of the murder of Britannicus, Lucan's passage on the execution of Marius Gratidianus and the narratives relating to the death of Vitellius (by Tacitus, Suetonius and Cassius Dio) are discussed in this context. 